\title{
CULTURE, RELIGION, AND ENGLISH TEACHERS' CONTRIBUTION IN INDONESIA
}

\author{
Andini Linarsih \\ Tanjungpura University Pontianak
}

\begin{abstract}
As culture and religion are indispensable part of the Indonesian society, understanding students' cultural and religious background constitutes one of the important factors in the success of foreign language teaching, particularly English. Non-native English speaking teachers can improve students' English competence because they are capable of bridging the cultural and religious differences between the source language and the target language as well as providing an easy-to-understand explanation regarding the vocabulary and grammatical aspects of the source language. In addition, they can better understand the students' needs and design a more realistic syllabus to overcome students' language barriers. However, the role of native English speaking teachers (NESTs) can also fill the weaknesses Non-native English speaking teachers (NNESTs) face in increasing the communicative competence. Therefore, better instruction is not merely related to the native or non native concepts. It lies on the personal qualities of the teachers to apply proper language teaching methods to boost students' communicative skills.
\end{abstract}

Keywords: Native English Speaking Teachers (NESTs), Non-Native English Speaking Teachers (NNESTs), Student, Culture, Religion.

\section{INTRODUCTION}

Culture, language and religion inter-relate with one another. Language is not only the product of culture, but also the symbol of culture itself (Gleason, 1961). Many cultures are closely related to a particular religion. The Arab culture, for instance, is heavily influenced by Islam. The Indian culture can never be separated from Hinduism. In many traditional communities in Indonesia, religion has been mixed with the local cultures and values. English, as the official language of the United States and Britain as well as several other western and commonwealth countries, brings with it the cultural values of its speakers wherever it spreads.

English has spread rapidly around the world. According to Crystal (2002, p. 2) English speakers nowadays range approximately between 700 million and 1 billion compared to an estimated to be 4 million in the year of 1500 . Kachru (1985) divided the spread of English in the world into three concentric circles namely the inner circle, outer circle, and extending circle. English is the primary language of the society in inner circle countries such as Britain, New 
Zealand, Australia, Canada and The United States. Outer circle countries, including Singapore, India, Nigeria and Malaysia, are countries where English plays important role as a 'second' or 'additional' language. They were under colonization by members of inner circle countries. Extending circle countries - such as Indonesia, Japan, China, and Laos - do not have the history of inner circle countries colonization and English is not their native language. They consider English important but they only perceive English as a foreign language.

People in the inner circle countries are defined as the native speakers of English while the ones in outer and expanding circles are non native English speakers. According to Kachru (as cited in McArthur, 1998, p. ) inner circle countries are 'norms-providing varieties', on the other hand; outer circle countries are 'norm-developing varieties and expanding circle countries are 'normdependent varieties'. All norms applied in English language system come from the inner circle countries as standard. It makes speakers coming from those countries considered to be good model of English teachers. There are many English teaching vacancies across the world widely welcome native English speaker teachers over non-native speakers. The definition of native speakers is problematic but in this paper native English speaker teachers (NESTs) in this paper are people who come from the inner circle countries, acquire and use English since early in their childhood, and have the physical appearance as the inner-circle countries people. Non-native English speaker teachers (NNESTs) are those who share the same first language and cultural background, have a high level of English proficiency, and have graduated from teacher training institute. This paper will argue that having NNESTs may benefit students, more over NESTs, in expanding circle countries because of the following reasons. First, NNESTs can explain the linguistic systems and rules well. Second, NNESTs can be motivators for students to learn English. The third, NNESTs can make realistic syllabus. Finally NNESTs also understand the importance of preserving local language.

As Rampton (1990) points out, 'being born to a group does not mean that you automatically speak its language well". He also added that English proficiency should be evaluated by 'what you know' rather than 'who you are. NNESs can be a good at explaining English lessons well because they must have completed their education from a teacher training faculty where they learn English linguistics systems from basic to advance. In Indonesia, students in the English teachers training department learn about each linguistic elements such as phonology, morphology, and syntax. They are trained how to produce each English sound, construct and understand the meaning of sentences 
correctly. They also learn to study how to apply strategies to increase the four language skills - listening, writing, speaking, and reading.

Furthermore, NNESTs are obliged to do three-months of teaching internship at schools before completing the study. Rampton (1990, p. 98) states that "expertise is learned, not fixed or innate". The sufficient linguistic knowledge enables NNESs to understand difficulties to reach the near-native competence. They can teach students how to overcome the difficulties based on their own experience. Cook (1999) as cited in Oka (2004, p.6) proposes that NNESTs are valuable sources to the learners since they can share learning experiences to overcome the problems and difficulties. Chen and Wang (2004) as cited in Nakata (2010, p. 77) points out that language teachers should first have practical command of the target language to develop EFL learners' language proficiency. With their three-month teaching experience at school before completing the study, NNESTs, Indonesian teachers for example, can learn how to transfer the theories into the practical command of teaching and learning in the classroom.

Native English speakers (NESs) who have undertaken similar TESL training in their countries may also be good at explaining the theories to the EFL students. However, there are some English (L2) concepts which cannot be found in students' L1 such as tenses, pronouns and pronouncing certain sounds. If NNESTs have limited knowledge in students' L1, they may find it difficult to explain to the students how to understand the differences because they do not undergo similar inter-language process to handle the L2 inputs with the students. Americans or Britons may find it easy to understand tenses but Japanese or Indonesian students may experience some developmental errors, for example in the overgeneralisation of the rule of -ed for the verb in Simple Past Tense, in understanding tenses. Further, NNESTs can use L1 to ensure that the knowledge has been perceived properly by the students by re-explaining the theory into L1 if the students still look confused, asking students to re-explain the theories or instruction in L1, using L1 structures in comparison with English to understand the distant linguistic system.

However, NESTs are ideal teachers to promote communicative competence in the classroom because they will make English the sole medium of instruction in the classroom. English-speaking atmosphere created by NESTs might force the students to use English all the time. NESTs may also explain all materials and the culture implied in the context well. However, this only works well with students in advance level who are not still struggling with limited vocabulary and already have sufficient English knowledge.

NNESTs sharing similar language and cultures with the students can make 
realistic syllabus. They are more sensitive to their students' difficulties in understanding the language. They can measure how long and how many times certain concepts should be taught. They can also measure the appropriate level of task difficulties. Those measurements can be their basis to choose effective teaching strategies that can be used. For example, they may use code switching to make their explanation easier to understand. Harmer (2001p. 131) points out the use of L1 in the classroom is almost inevitable since it shows that students try to make sense of a new linguistic form through the linguistic form that they are already familiar with.

Moreover, NNESTs can teach lessons with the adjustable speaking pace to the pace, speaking at a pace that their students can understand. However, NESTs needs some years of experience in the target country to slow down their speaking pace in order to EFL students understand. They can read from the students gestures or body language to know whether the students understand the explanation or not. They can approach the students outside the classroom to find out the problem and discuss the problems in their mother tongue. Moreover, Eldrigde 1996 as cited in Harmer (2001,p. 131) states that 'codeswitching between L1 and L2 is naturally development and not some example of misguided behavior". NNESTs can take advantage over this situation because they understand the language. They can analyse the difficulties the students encounter to reevaluate their teaching styles, approach and materials to become more effective teaching. During the class NNESTs can use students L1 to ensure whether the students understand the materials of not. In Indonesia where grammar-based test is applied, understanding of tenses is imperative. Conversely, linguistic system in Bahasa Indonesia (students' L1) does not have such a system.

On the other hand, NESTs may be less sensitive to the values that the students have such as that teachers are always right, they cannot contradict the teacher, and making eye contact with teachers means rebellious actions. They must understand the culture in the classroom that Indonesian students have been living with. NESTs grow up with the culture that during the class students' eye contact to teachers symbolise good attention; on the other hand, in Indonesia casting down students' eyes when teachers are speaking are culturally taught. If NESTs do not know this, they will consider Indonesian students impolite and may reprimand the students. Silence means students respect the teachers and can also mean they understand the lesson. If NNESTs do not have the understanding of these beliefs they can misinterpret the students' behaviour in the classroom which can make huge gap between teacher and students. 


\section{CULTURAL AND RELIGIOUS AWARENESS}

Teaching English in a predominantly Muslim country, such as Indonesia, is challenging for both NESTs and NNESTs. That being said, they should be aware of the sensitivity regarding cultural and religious values, as these values are embedded in the society. A better understanding of differences in culture and religion may bridge a communication gap between teachers and students. This might seem trivial, but to a certain degree, any activities and approach used in teaching the language should well-planned.

NESTs should have the knowledge that religion is indispensable part of Education in Indonesia. Religious values are embedded in every teaching. They should carefully pick any topics or culture that is not contradictory to students' religious teaching. Since Indonesia is the biggest Muslim country in the world, it is suggested that all NESTs should be aware of actions that are prohibited by their students' faith. Taken for example, If the topic is about family, NESTs should be careful of not asking students talking about what they do not like about their parents. Students in Indonesia will reluctantly answer that question because it is against their religious teaching. For Muslim students, they are taught to respect their parents, never say bad things about them especially in public. Even say 'ah' to what their say is prohibited and considered as an insubordinate action. The Quran says:

"And your Lord has decreed that you not worship except Him, and to parents, good treatment. Whether one or both of them reach old age [while] with you, say not to them [so much as], "uff," and do not repel them but speak to them a noble word. (Al-Israa': 23).

NNESTs on the other hand will not face difficulties to choose insensitive topic to talk about. Moreover, NNESTs who have learnt English and experience living in an English-speaking country will make use of the culture shocks to strengthen students' faith. They may tell their students of how they adapt to culture shocks, what lessons they learn from that situation, and how culture clashes with their belief that only strengthens their faith when NNESTs are discussing a topic related to their experience in the classroom.

Lack of motivation is always an issue in EFL countries. Teachers have a big role to providing extrinsic motivation their students. NNESTs can be a good motivator for their students because students can see real examples of people who have the similar linguistic knowledge who can successfully learn English. According Medgyes (1992, p.347) NNESTs are imitable models of successful learners of English. They serve as living proof of how people in same English proficiency are possible to achieve only by studying in their own country. NNESTs' effective teaching strategies, followed by a reasonable speaking pace, 
can make each lesson easy to follow.

If English is easy to follow and to understand, the students will consider it as an achievable lesson. According to Atkinson and Raynor (1974) as cited in Dornyei and Ushioda $(2001,14)$ one of students achievement motivation is based on the fear of failure. If the students feel that the subject is too difficult to understand and they also experience with low marks most of the time, they will become de-motivate to study the lesson. NNESTs can understand this fear of failure that they student feel because they may have experience the same feeling as well when they learn. So they will tend to set more realistic goals and lesson plans for their teaching. They may know what kind of effective teaching strategies to make the lesson achievable for the students.

In practical classes, one of the strategies that NNESTs usually use when they face lower to intermediate proficiency students is by explaining the lesson using mother tongue (Zacharias, 2003). Shishavan (2010) also shows that male Iranian students prefer their teachers who explain the lesson with mother tongue as effective English teachers. As Canagarajah (1999) proposed (as cited in Zacharias, 2001, p. 36) that L1/mother tongue used in the classroom may promote a relaxed learning atmosphere since it diminishes students hesitance, fear and nervousness. Relaxed learning atmosphere will benefit to low level of anxiety so that students can participate more in the classroom. Knibbeler (1989) as cited in Zacharias (2003) points out the language learning which can provide lower level of anxiety is the best situation for language learning. Nunan (p. 235, also supported the precondition of effective motivation in classroom as the teachers' ability to manage the classroom so students will not feel anxious and will feel comfortable to take risks.

\section{CROSS-CULTURAL UNDERSTANDING}

Both NESTs and NNESTs should have better insight into understanding different a culture. Therefore, in this case, cross cultural understanding should be among the crucial issues teachers (both NESTs and NNESTs) learn before departing on their EFL teaching journey. To have the first hand experience with the culture of the source/target language, it would be a privilege for language teachers to have an opportunity to study and live in the community where the language is spoken. This can be done through exchange programs or overseas studies which are provided by many countries in the form of competitive scholarships. So, teachers should inspire students to pursue overseas studies to gain the knowledge and experience that cannot be found in their home country. 
NNESTs can be good motivators for their students in term of instrumental orientation for their students. Instrumental orientation according to Gardner and Lambert (1972) as cited in Brown (2007, p. 88) is the desire to learn a language to attain certain education goal. They are many scholarships given by USA, Australia and Britain through foundations such FULBRIGHT, IIEF, Ausaid for people in developing countries such as Indonesia, Laos, Vietnam, and Bangladesh to experience learning, teaching and living in those inner circle countries. NNESTs who receive that experience will share their experience to live and travel overseas because of their English ability to their students. Their stories may give some students another reason why they need to study English harder. For students who are interested to pursue the same experience as the teachers, they will be extrinsically motivated.

On the other hand, NESTs can also be good motivators for students in advance level because they use 'real language' and bring the real culture (Medgyes, 2006, p. 435). Advance level students usually aim to higher level of proficiency and to have near native. For those students the native speakers can excite them about the language, by introducing the related culture of the native speaker. By explaining the cultural background, the students can envisage exploring these new realms, exotic from their own experience. They also remind the students of the real life application of the language. The level of fluency can also provide a real challenge for the higher level students, to really develop their language to the point of near native fluency.

NNESTs can benefit the English language teaching in term of preserving local language. Local language can be preserved by the use of students L1 as the tool to understand L2. In practical classroom NNESTs may sometimes use comparison and contrast analysis between L2 and L2. For example, NNESTS may compare or contrast local language sentence construction to L2 sentence construction as part of their teaching strategies. They are also being able to link the certain sounds in English with the similar sounds in local language in comprehending the listening tasks. These strategies make students value their local language as the bridge to comprehend the foreign language. According to Ringbom (1987, p. 52) language transfer from L2 to L1 assists the learners to analyse the knowledge to cope with a gap of knowledge. Seidlhofer (1999, p. 235) also supported this idea by stating that non-native EFL teachers are 'double agents' sharing similar language and culture to facilitate learning by bridging different language and culture of L1 and L2 through appropriate pedagogy. Understanding students' L1 and L2 can help NNESTs understand how to explain the L2 in line with students' ways of thinking.

NNESTs can also prevent language loss. The issue of language loss in 
expanding countries may be the result from the neglecting the local accent in speaking and having standardized pronunciation, mostly British or American accents, by the EFL learners. It is because they speak English they still carry their local accent. Having local accent is the other issue EFL teaching which speaking is the main parameter in judging learners' English competence. The speaking ability that the learners have are considered not only from how myriads vocabulary they have but also from how close their pronunciation or accent to standardized English pronunciation. Some parents who feel that their distinctive mother tongue accent in speaking English inhibits them to reach near native proficiency will then try not to teach their local language to their children. They may not speak their local language at home with their children. They prefer to use English at home as much as they can and enrol their students to bilingual or international schools. This condition endangers local language.

According to Grenoble (2006) the primary cause of language loss is speakers are in favour of speaking the other language which can benefit them for economical or political reasons, and as the result they cease to speak their own native tongue or local language. Schaefer and Egbokhare 1999 as cited in McKay (2002, p. 21) states that indigenous minority languages were abandoned because of the important role of English in Nigeria. There are also some endangered indigenous languages because of the presence of English as the policy of the government such Siletz Dee-ni in Canada and Yuchi in U.S.A where the teaching of English has made many local languages disappear because the next generation do not use them anymore like Irish Gaelic, for example, has shifted the first language to become the second language.

NNESTs can become a good model for their students that the most important thing in English speaking in international communication is the intelligibility. McKay (2002, p. 52) states that intelligibility is the recognitions of the uttered sound. To make the sound is intelligible does not always mean that you have native pronunciation. NNESTs will tell the students that English conversation with the other international people can run smoothly even though they have imperfect accents. However, NESTs may not be pay much attention to preserve the local language.

To sum up, non native English speaking teachers can increase students English competence in English because they can explain the knowledge well, they understand the students more to make the more realistic syllabus and they can preserve local language to extinct. However, the role of native English speaking teachers (NESTs) can also fill the weaknesses NNESTs face in promoting the communicative competence. Therefore, the best teacher is not related to the 
native or non native concepts. It lies on the own personal qualities of the teachers to keep on improving their qualities and understanding learners better.

\section{CONCLUSION}

Language, culture, and religion should be treated as inter-connected elements that one cannot be taken away from the others. Each of them complements the rest, and therefore both NESTs and NNESTs should be sensitive to cultural and religious issues in their teaching. As most Indonesians are traditionally religious, designing activities for use in an English language classroom setting should take cultural and religious values into consideration. Native English speaking teachers are certainly needed for teaching linguistic aspects that Non-native English speaking teachers may find difficulties with such as pronunciation and natural speech. However, being able to present the material in a manner that fills the gap of cultural and religious differences between the source language and the target language is not to be ignored. Thus, successful language teaching is not a matter of being a native or non native of a particular language. It is heavily related to both the teachers' use of well-planned teaching methods and sensitivity or respect toward traditional values embedded in culture and religion

\section{BIBLIOGRAPHY}

Brown, H. (2007). Teaching by principles: an interactive approach to language pedagogy. New York: Pearson Education.

Harmer, J. (2001). The practice of English language teaching. England: Person Education Limited

McArthur, T. (1998). The English Languages. Cambridge: Cambridge University Press.

McKay, S. (2002). Teaching English as an international language. New York: Oxford University Press.

Medgyes, P. (2006). When the teacher is a Non-Native Speaker. In M. Celce-Murcia (Ed.) Teaching English as a Second or Foreign Language (pp. 429-442). Beijing: Foreign Language teaching and Research Press.

Mizuno, C. (no year). Non-native English speakers of English teaching in Japan - critical perspectives on TESOL in an educational context. Retrieved November 4, 2010 from:

http://www.paaljapan.org/resources/proceedings/PAAL9/pdf/MizunoCh. 
pdf.

Nakata, Y. (2010). Improving the classroom language proficiency of non-native teachers of English: what and how?. RELC journal (41)1 76-90.

Nunan, D. (1999). Second language teaching and learning. Boston : Heinle \& Heinle.

Oka, H. (2004). A Non-native Approach to ELT: Universal or Asian?. Retrieved November 4, 2010, from:

http://www.asian-efl-journal.com/images/04_ho.pdf.

Pasternak M, and Bailey KM (2004) 'Preparing Nonnative and Native English-speaking Teachers: Issues of Professionalism and Proficiency' In Kamhi-Stein LD (ed.) Learning and Teaching from Experience: Perspectives on Nonnative English-speaking Professionals. Ann Arbor: The University of Michigan Press, 155-75.

Rampton, M. 1990. Displacing the 'native speaker: expertise, affiliation, and inheritance. ELT journal 44/2, pp. 97-101.

Seidlhofer, B. (1999) Double standards: teacher education in the Expanding Circle, World Englishes, 18(2):233-244.

Shishavan, $\mathrm{H}$. The relationship between Iranian English language teachers' and learners' gender and their perception of an effective Engliah language teacher. English Language Teaching. English Language Teaching Journal 3(3) www.ccsenet.org/elt. retrieved on November 4th, 2010.

Zacharias, N. (2003). A survey of tertiary teachers' beliefs about English Language Teaching in Indonesia with regard to the role of English as a global language. http://www.asian-efl-journal.com/thesis.php. 20 October 2010. 